\title{
The Efficacy of Art Therapy on Mental Health Outcomes Among Breast Cancer Patients: The Current State of Evidence Based on Randomised Controlled Trials
}

Azmawati MN, Boekhtiar B, Zawiah M, Siti Aisah M, Chiew WL, Dalila R.

Department of Community Health, UKM Medical Centre, Universiti Kebangsaan Malaysia Medical Centre (UKMMC), Jalan Yaacob Latif, Cheras, 56000 Kuala Lumpur, Malaysia.

\section{ABSTRACT}

Introduction: Breast cancer is the most common cancer among women. Psychosocial distress, in the forms of depression and anxiety, regularly accompanies breast cancer diagnosis and throughout its treatment. Hence, it is important to objectively assess the therapy options that may help this distress. One of the most flexible psychotherapy modalities is the art therapy as it may be incorporated in many settings. The purpose of this systematic review is to determine the efficacy of art therapy (via creative paintings) on the mental health outcomes of female breast cancer patients. Material and Methods: Related articles were identified from Medline (OvidSP), ScienceDirect, Pubmed, EbscoHost-Academic Search Premier and Wiley Online Library. Screenings were performed based on the criteria that the study must be a randomised control trial (RCT) that investigated the effect of art therapy in breast cancer. Data were extracted using standardised forms, followed by evaluation of quality of reporting using CONSORT Guidelines. Results: Six RCTs were identified. Based on the heuristic synthesis of data extraction results, none of the studies can be considered as studies with acceptable quality, although four of them showed promising results. Conclusion: There is inconclusive evidence of the efficacy of art therapy (via creative paintings) for the improvement of mental health outcomes among female breast cancer patients.

KEYWORDS: Art therapy, breast cancer, breast neoplasm, systematic review INTRODUCTION

Breast cancer is the most common cancer among women and the second commonest cancer in human, accounting for 1.1 million new cases out of 11.5 million cancers cases worldwide in $2004 .{ }^{1}$ As in all forms of cancer, a breast cancer diagnosis (and treatment) may cause psychosocial distress to its victims. According to a cohort study in England among 222 women with early stage of breast cancer, nearly $50 \%$ of them had depression, anxiety

Corresponding Author:

Azmawati Mohammed Nawi

Department of Community Health,

Faculty of Medicine,

Universiti Kebangsaan Malaysia Medical Centre,

56000 Kuala Lumpur, Malaysia.

Phone : 03-91458901

Fax : 03-91456670

Email : azmawati@ppukm.ukm.edu.my or both in the first year after diagnosis. ${ }^{2}$ This annual prevalence dropped to $15 \%$ by the fifth year after diagnosis. According to Burgess et al., (2005) the risk factors for depression and anxiety are associated with the characteristic of patients, rather than to the cancer itself or its treatment. ${ }^{2}$ In a narrative review by Fann et al., (2008) it was stated that psychosocial interventions (i.e., psychotherapies) have mixed results in term of the improvement of general mood, distress, depression and anxiety among cancer patients. ${ }^{3}$ On the other hand, a systematic review by Williams and Dale (2006) found that that there were some evidence of the efficacy of psychotherapeutic interventions on the depressive symptoms among cancer patients. ${ }^{4}$

Among the myriad of psychotherapy modalities, art therapy can be seen as method that primarily focuses on the expressive capabilities of its clients. 
According to one definition, art therapy encompasses the use of different art media, whereby the client can express and work through the issues and problems that require psychotherapeutic intervention. ${ }^{5}$ A more thorough conceptual definition by the American Art Therapy Association in their mission statement in 1996 focuses on the healing and life enhancement through creative process of art, which can be seen as a primary form of nonverbal communication of cognition and emotion. ${ }^{6,7}$ It can be seen as a modality that create meaning and insight in the process of finding respite from emotional burden or trauma. ${ }^{8}$ On the other hand, it should be noted that there are also various approaches in the art therapy -ranging from the eclectic (i.e. nonspecific) approaches as practiced by most therapists to the more obscure psychodynamic approaches that focus in the mysterious realm of the unconscious. ${ }^{9}$

A systematic review by Slayton et al.(2010) based on 35 qualitative and quantitative studies found a varying degree of evidence that art therapy does work in various settings, although most of these studies do not meet the highest standard in efficacy research. ${ }^{10} \mathrm{~A}$ more specific systematic review by Archer et al., (2015) on creative psychological intervention (that includes art, dance, drama and music therapies) concluded that there is promising initial evidence that this form of intervention benefits adult cancer patients in terms of anxiety and depression, quality of life, coping and mood. ${ }^{11}$

Search of electronic databases:

MEDLINE (OvidSP), PubMed, ScienceDirect, Academic Search Premier (EbscoHost), Wiley Online
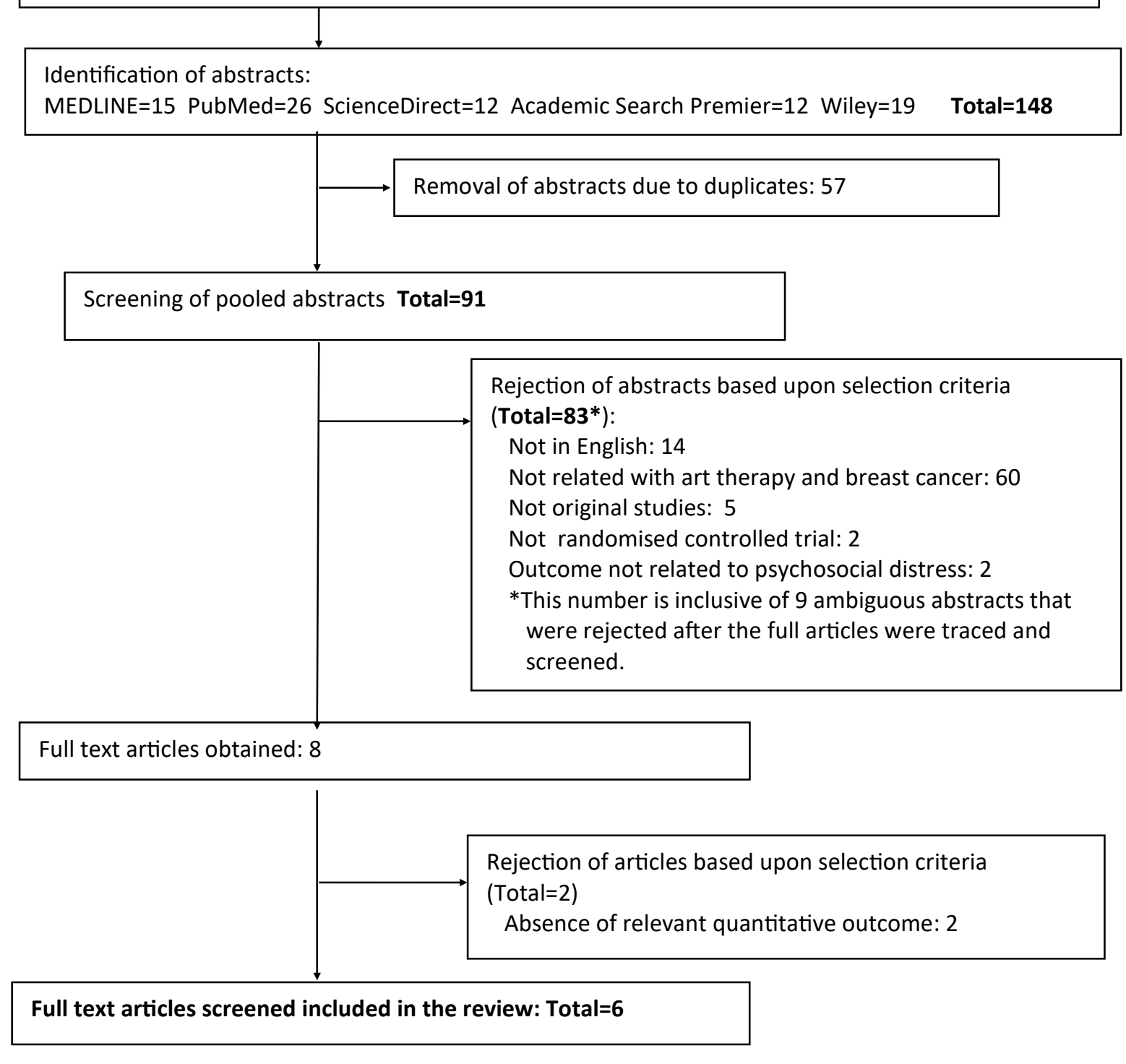

Figure 1: Flowchart to show the selection process of the articles in this review. 
Conversely, a systematic review and meta-analysis by Boehm et al.,(2014) concluded that "art therapies" positively affect patients' anxiety, but not depression or quality of life. ${ }^{12}$ This systematic review focused on the efficacy of art therapy (via creative paintings) on the mental health outcomes of female breast cancer patients, based only on past randomised controlled trials. The specific designs, results and quality of each of these studies were dissected for the synthesis of coherent conclusion about the current state of evidence.

\section{MATERIALS AND METHODS}

Based on current trend to minimise bias in the reviewing process, we followed the recommended steps for systematic review by Needleman (2002). ${ }^{13}$ At the same time, we made some minor adjustments to the procedure as to improve the objectiveness of the review.

\section{Study selection}

We conducted a systematic electronic search in five databases i.e. MEDLINE [OvidSP], ScienceDirect, Pubmed, EbscoHost-Academic Search Premier and Wiley Online Library; that comprised a publication timeline from the earliest date possible to the end of September 2014. The search strategy included the following terms and Boolean operators: 1) breast cancer*; 2) Art therapy*; 3) 1 AND 2 (abstract/title field only). A total of 148 individual abstracts were identified (Figure 1). In the first stage, screening of abstracts were included in the review based upon these criteria: a) the study reported the effects or association between breast cancer and art therapy; b) it is an original study; c) it is a randomised controlled trial (RCT); and d) written in English. At the same time, abstracts were excluded from the review if: a) the study was related "art-based therapies" that are not under the definition or art therapy in this review (e.g. music, dance and drama therapy); or b) the study did not have any psychological outcomes. Ambiguous abstracts were excluded only after their full papers were traced and screened in the next phase. Any discrepancies in the results of the screening were resolved through a consensus process.

The first stage screening yielded eight abstracts that fulfilled the selection criteria. This phase was followed by tracing the full articles for each abstract electronically. The downloaded articles were then subjected to a second round of screening by two researchers using a standardised electronic form independently. In the second stage, the study would be rejected from the review if: a) the effect of the RCT was not measured using any quantitative mental health-related inventories; or b) the analyses included male breast patients. Again, any disagreements in the screening results were settled by mutual consensus. Through these two-phased screening, only six full articles were finally included in the review (refer Table 1). It should be noted that all these studies were included in this systematic review, regardless of their quality, due to the lack of identified articles. This is contrary to the ideal practice of including only studies with high methodological quality in a systematic review. ${ }^{20}$

\section{Data extraction}

To reduce bias, the data extraction procedure for the studies was also done by two researchers. This procedure was performed using three different electronic forms i.e. i) the study design form, ii) the study results form and iii) the study report quality form.

In the study design form, the following information was recorded: a) classification of RCT design (by assignment, proof type and confirmatory/ exploratory nature); b) sample characteristics (age, breast-cancer stage, medical treatment state); c) type of art therapy; d) sampling method used, sample and size of each group; e) intervention description in the control and comparison group; f) length of intervention; g) psychological questionnaire used and its measured construct; $h$ ) reliability \& validity of each psychological inventory used in the study (based on study population and not literature review); i) analysis type (per protocol or intention-to-treat); and j) main outcome measure (s). On the other hand, the study results form required the researchers to record the following information: a) reported descriptive values of main outcome measure(s); b) reported inferential statistical analysis; c) result summary; and d) conclusion of the effect of art therapy in breast cancer cases. During the tabulation of the results, we also recalculated the effect size of the art therapy intervention based on the reported 
descriptive results to ensure a clearer conclusion later on. ${ }^{21}$

Finally, the quality of the study report was assessed using two different checklists based upon the Consolidated Standards of Reporting Trials (CONSORT) Statement. ${ }^{22}$ The CONSORT Statement checklist was used to assess the quality of the controlled trials in the review, whereas the Strengthening Reporting of Observational studies in Epidemiology (STROBE ) checklist was used for the cohort study. The grading of the items in the checklists was created for the purpose of this review to correspond to the following subjective assessments: a) acceptable; b) some minor weaknesses; c) some major weaknesses; d) not acceptable; and e) ambiguous.

\section{RESULTS}

\section{Summary of study designs of the included studies}

Based on Table I, all the studies were parallel in design, without blinding or placebo-controlled. Besides that, all the studies were done in developed countries. Non-probability sampling was the method to enrol subjects in all these studies. The lowest sample size was $37^{19}$ and highest number of sample size was $191 .^{18}$ Besides that, baseline characteristics between the intervention group and control group were poorly described in most of the studies - some of them even showed evidence of imbalance in age. $^{16,17,19}$ There was no significant difference of outcome measures between the intervention and control groups at pre-intervention period in all the studies. Fours studies excluded subjects with psychiatric illness, ${ }^{14}, 16,17,19$ whereas the other two did not state this important exclusion criteria. ${ }^{15,18}$ None of the studies provided the reliability and validity of the measurements inside the study itself (i.e. all were based on literature).

In terms of the art therapy intervention, four studies ${ }^{14,16,17,19}$ used the phenomenological method as described by Betensky (1995), ${ }^{23}$ whereby the five weekly sessions were divided into the following: a) one session involving visualisation of feelings as analogue of drawings; b) one session involving creation of a life-size body image to express the different feelings in her body using shapes and colours; c) two free-painting sessions; and lastly by d) one session where reflection was done by the patient to summarise her creative journey. Two studies used non-specified art therapy procedure in combination with meditation. ${ }^{15,18}$ The length of intervention for these two studies ranged from four weekly sessions ${ }^{15}$ to eight weekly sessions. ${ }^{18}$

\section{Summary of results of the included studies}

Due to the variety of outcome measures in the six studies, we have clustered the outcomes into three main domains of mental health outcome; a) positive psychology domain (Coping Resource Inventory ${ }^{14}$ and Emotional Approach Coping Scale ${ }^{15}$ ); b) mental illness domain (Profile of Mood States ${ }^{15}$ and Symptom Check List-90 $0^{17,18}$ ); and quality of life domain (WHOQOL-BREF ${ }^{16,19}$, QLQ-BR23 ${ }^{16}$ and SF $-36^{18}$ ). Based on Table II, art therapy group has significantly better mental health outcomes compared to control group in four different studies. ${ }^{15-17,19}$ For the mixed art-therapy-andmeditation study by Puig et al.,(2006) ${ }^{15}$ it was shown that there was significant improvement mood after four weeks post-intervention, whereby its effect size on depression was large (Cohen's d: 0.83) and its effect size on anxiety was medium (Cohen's d: 0.59). For the studies using Betensky's method, positive significant results can only be seen in three studies, in terms of ; a) significant general distress improvement after four months post-intervention with small effect size (Cohen's d: 0.03$)^{17}$; and b) significant improvement of quality of life after 6 months post-intervention with small (Cohen's d: $0.13)^{16}$ to large (Cohen's d: 1.05$)^{19}$ effect sizes.

None of the studies showed significant results for the positive psychology domain, in terms of coping. As a whole, the Cohen's d effect size of art therapy (compared to control) on each domain of mental health outcomes ranged as follows; a) positive psychology domain: 0.02-0.63; mental illness domain: 0.03-0.83; and quality of life: 0.031.05. Due to the heterogeneity of the designs, we did not proceed with a meta-analysis to prevent misleading synthesis of varied quantitative outcomes.

\section{Summary of quality of the included studies}

Referring to Table III, none of the six studies fulfilled the minimum assessment category of 'some minor weaknesses' in all 27 items in the methods and results section of the CONSORT statement checklist. For example, none of the study described the statistical calculation to justify their sample size. On top of that, randomisation procedure was 
poorly reported in most of the studies (except Svensk et al., (2009), ${ }^{16}$ and most importantly, there was also lack of blinding and placebo control in all the studies. These weaknesses caused the studies to be open to criticism for selection and experimenter biases that may skewed the results.

Table I: Evidence Table for the Study Design of Past Studies on the Effect of Art Therapy In Breast Cancer Patients

\begin{tabular}{|c|c|c|c|c|c|c|}
\hline Study & RCT Design & $\begin{array}{l}\text { Sampling and sample } \\
\text { characteristics }\end{array}$ & $\begin{array}{l}\text { Art therapy } \\
\text { intervention } \\
\text { description }\end{array}$ & $\begin{array}{l}\text { Control/ } \\
\text { comparison } \\
\text { group(s) } \\
\text { description }\end{array}$ & $\begin{array}{l}\text { Length of } \\
\text { Intervention }\end{array}$ & $\begin{array}{l}\text { Relevant main } \\
\text { outcomes and } \\
\text { their } \\
\text { psychometric } \\
\text { properties }\end{array}$ \\
\hline $\begin{array}{l}\text { Oster et } \\
\text { al. } \\
(2006)^{14}\end{array}$ & $\begin{array}{l}\text { Parallel/ } \\
\text { superiority/ } \\
\text { confirmator } \\
\text { y }\end{array}$ & $\begin{array}{l}\text { - Purposive sampling } \\
\text { among } 41 \text { Swedish } \\
\text { women with primary } \\
\text { non-metastatic breast } \\
\text { cancer who were } \\
\text { undergoing } \\
\text { radiotherapy (median } \\
\text { age: } 59 \text { ). } \\
\text { - Exclusion of women } \\
\text { with dementia or } \\
\text { severe psychiatric } \\
\text { illness. } \\
\text { - Stratified } \\
\text { randomisation done } \\
\text { (based on } \\
\text { postoperative } \\
\text { chemotherapy status) } \\
\text {-intervention group } \\
\text { (n=20) versus control } \\
\text { group (n=21) } \\
\text { - Baseline } \\
\text { characteristics: } \\
\text { - Comparison in } \\
\text { terms of age, } \\
\text { breast cancer stage } \\
\text { and medical } \\
\text { treatment state } \\
\text { were not } \\
\text { described. } \\
\text { Outcome measures } \\
\text { were not different } \\
\text { between the } 2 \\
\text { groups. } \\
\text { - }\end{array}$ & $\begin{array}{l}\text { Tndividual art } \\
\text { therapy } \\
\text { session once a } \\
\text { week during } \\
\text { radiotherapy } \\
\text { using } \\
\text { phenomenolog } \\
\text { ical method } \\
\text { (as described } \\
\text { by Betensky): } \\
\text { - First session: } \\
\text { visualisation } \\
\text { of feelings as } \\
\text { analogue } \\
\text { drawings. } \\
\text { - Second } \\
\text { session: made } \\
\text { a life-size } \\
\text { body image to } \\
\text { express } \\
\text { different } \\
\text { feelings in } \\
\text { her body } \\
\text { through } \\
\text { shapes and } \\
\text { colours } \\
\text { - Third and } \\
\text { fourth } \\
\text { session: paint } \\
\text { whatever. } \\
\text { - Fifth session: } \\
\text { reflection (a } \\
\text { summary of } \\
\text { her creative } \\
\text { journey) }\end{array}$ & $\begin{array}{l}\text { Procedure } \\
\text { in control } \\
\text { group was } \\
\text { not } \\
\text { described }\end{array}$ & $\begin{array}{l}\text { Once a week } \\
\text { for } 5 \text { weeks } \\
\text { during } \\
\text { patients } \\
\text { radiotherapy } \\
\text { treatment. }\end{array}$ & $\begin{array}{l}\text { Measurement of } \\
\text { the following } \\
\text { scales at 0 } \\
\text { month (pre } \\
\text { intervention), } 2 \\
\text { months and 6 } \\
\text { months post } \\
\text { intervention } \\
\text { period: } \\
\text { 1. Coping } \\
\text { ResourcesInvent } \\
\text { ory to measure } \\
\text { changes in } \\
\text { coping resources } \\
\text { - 5 domains: } \\
\text { cognitive, } \\
\text { social, } \\
\text { emotional, } \\
\text { physical, and } \\
\text { spiritual, } \\
\text { philosophical. } \\
\text { (Reliability and } \\
\text { validity in the } \\
\text { study no } \\
\text { described) }\end{array}$ \\
\hline $\begin{array}{l}\text { Puig et } \\
\text { al. } \\
(2006){ }^{15}\end{array}$ & $\begin{array}{l}\text { Parallel/ } \\
\text { superiority/ } \\
\text { exploratory }\end{array}$ & $\begin{array}{l}\text { - Purposive sampling } \\
\text { among 39American } \\
\text { women who were } 18 \\
\text { years and above and } \\
\text { have been diagnosed } \\
\text { with Stage I or Stage II } \\
\text { breast cancer within } \\
12 \text { months prior to the } \\
\text { study. } \\
\text { - Not stated whether } \\
\text { there was exclusion of } \\
\text { women with dementia } \\
\text { or severe psychiatric } \\
\text { illness. } \\
\text { - Randomisation done- } \\
\text { intervention group } \\
\text { (n=20) versus control } \\
\text { group (n=19) } \\
\text { - Baseline } \\
\text { characteristics: } \\
\text { - Comparison in } \\
\text { terms of age, } \\
\text { breast cancer stage } \\
\text { and medical } \\
\text { treatment state } \\
\text { were not } \\
\text { described. } \\
\text { - Outcome measures } \\
\text { were not different } \\
\text { between the } 2 \\
\text { groups. }\end{array}$ & $\begin{array}{l}\text { Tndividual } \\
\text { counselling } \\
\text { session that } \\
\text { involved: } \\
\text { osemi- } \\
\text { structured } \\
\text { creative art } \\
\text { therapy } \\
\text { experiences, } \\
\text { where } \\
\text { creative } \\
\text { freedom was } \\
\text { encouraged in } \\
\text { order to } \\
\text { facilitate and } \\
\text { explore the } \\
\text { woman's } \\
\text { emotional } \\
\text { expression, } \\
\text { spirituality, } \\
\text { and } \\
\text { psychological } \\
\text { well-being } \\
\text { state } \\
\text { - Guided } \\
\text { meditation to } \\
\text { help with } \\
\text { exploration of } \\
\text { spiritual } \\
\text { themes }\end{array}$ & $\begin{array}{l}\text { Delay of } \\
\text { individual } \\
\text { counselling } \\
\text { session over } \\
4 \text { weeks } \\
\text { (i.e. the } \\
\text { similar } \\
\text { intervion to } \\
\text { interventio } \\
\text { n group } \\
\text { would only } \\
\text { start after } \\
\text { the } \\
\text { interventio } \\
\text { n group } \\
\text { finished its } \\
\text { sessions) }\end{array}$ & $\begin{array}{l}4 \text { individual } \\
\text { therapy over } \\
4 \text { weeks-- } 60 \\
\text { minutes for } \\
\text { each session }\end{array}$ & $\begin{array}{l}\text { Measurement of } \\
\text { the following } \\
\text { scales after } 4 \\
\text { weeks of } \\
\text { intervention } \\
\text { period: } \\
\text { 1. Emotional } \\
\text { Approach Coping } \\
\text { Scale to assess } \\
\text { emotional } \\
\text { expression-- } \\
\text { processing } \\
\text { emotion and } \\
\text { expressing } \\
\text { emotion. } \\
\text { (Reliability and } \\
\text { validity in the } \\
\text { study no } \\
\text { described) } \\
\text { 2. Expressions of } \\
\text { Spirituality } \\
\text { Inventory to } \\
\text { measure } \\
\text { spirituality. } \\
\text { (Reliability and } \\
\text { validity in the } \\
\text { study were not } \\
\text { described) } \\
\text { 3. Profile of Mood } \\
\text { States to } \\
\text { measure mood } \\
\text { disturbance } \\
\text { score }\end{array}$ \\
\hline
\end{tabular}


Con't

\begin{tabular}{|c|c|c|c|c|c|c|}
\hline $\begin{array}{l}\text { Svens } \\
\text { k et } \\
\text { al. } \\
(2009)\end{array}$ & $\begin{array}{l}\text { Parallel/ } \\
\text { superiority } \\
/ \\
\text { explorator } \\
\text { y }\end{array}$ & $\begin{array}{l}\text { Purposive sampling } \\
\text { among } 42 \text { Swedish } \\
\text { women with non- } \\
\text { metastatic breast } \\
\text { cancer who were } \\
\text { undergoing post- } \\
\text { operative } \\
\text { radiotherapy. } \\
\text { - Exclusion of women } \\
\text { with dementia or } \\
\text { severe psychiatric } \\
\text { illness. } \\
\text { Randomisation } \\
\text { done-intervention } \\
\text { group (n=21) versus } \\
\text { control group (n=20) } \\
\text { Baseline } \\
\text { characteristics: } \\
\text { - median age for } \\
\text { intervention group } \\
\text { (59years) was } \\
\text { higher than control } \\
\text { group (55 years). } \\
\text { - Comparison of } \\
\text { breast cancer stage } \\
\text { and medical } \\
\text { treatment state } \\
\text { not described. } \\
\text { - Outcome measures } \\
\text { were not different } \\
\text { between the } 2 \\
\text { groups. } \\
\text { - }\end{array}$ & $\begin{array}{l}\text { Individual art } \\
\text { therapy using } \\
\text { phenomenologica } \\
\text { method (as } \\
\text { described by } \\
\text { Betensky). } \\
\text { The aim of the } \\
\text { intervention was } \\
\text { to (1) offer time } \\
\text { and space for } \\
\text { expression and } \\
\text { reflection; (2) } \\
\text { give support in } \\
\text { the process of } \\
\text { restoring body } \\
\text { image; and (3) } \\
\text { reduce stress and } \\
\text { supporting } \\
\text { agency. }\end{array}$ & $\begin{array}{l}\text { Procedure } \\
\text { in control } \\
\text { group was } \\
\text { not } \\
\text { described. }\end{array}$ & $\begin{array}{l}5 \text { weeks } \\
\text { during } \\
\text { patients' } \\
\text { radiotherapy } \\
\text { treatment } \\
\text { (frequency } \\
\text { of session } \\
\text { per week } \\
\text { was not } \\
\text { stated) }\end{array}$ & $\begin{array}{l}\text { Measurement of } \\
\text { the following } \\
\text { scales at pre- } \\
\text { intervention, } 2 \\
\text { months and 6 } \\
\text { months post } \\
\text { intervention: } \\
\text { 1. WHOQOL-BREF to } \\
\text { identify Quality of } \\
\text { Life and general } \\
\text { health - 4 domains } \\
\text { physical health, } \\
\text { psychological } \\
\text { health, social } \\
\text { relationship and } \\
\text { environment. } \\
\text { (Reliability and } \\
\text { validity in the } \\
\text { study were not } \\
\text { described) } \\
\text { 2. EORTC Quality of } \\
\text { Life Questionnaire } \\
\text { [(QLQ)-BR23]to } \\
\text { identify Quality of } \\
\text { Life in breast } \\
\text { cancer patients. } \\
\text { (Reliability and } \\
\text { validity in the } \\
\text { study were not } \\
\text { described) }\end{array}$ \\
\hline $\begin{array}{l}\text { Thym } \\
\text { e et } \\
\text { al. } \\
(2009)\end{array}$ & $\begin{array}{l}\text { Parallel/ } \\
\text { superiority } \\
/ \\
\text { explorator } \\
\text { y }\end{array}$ & 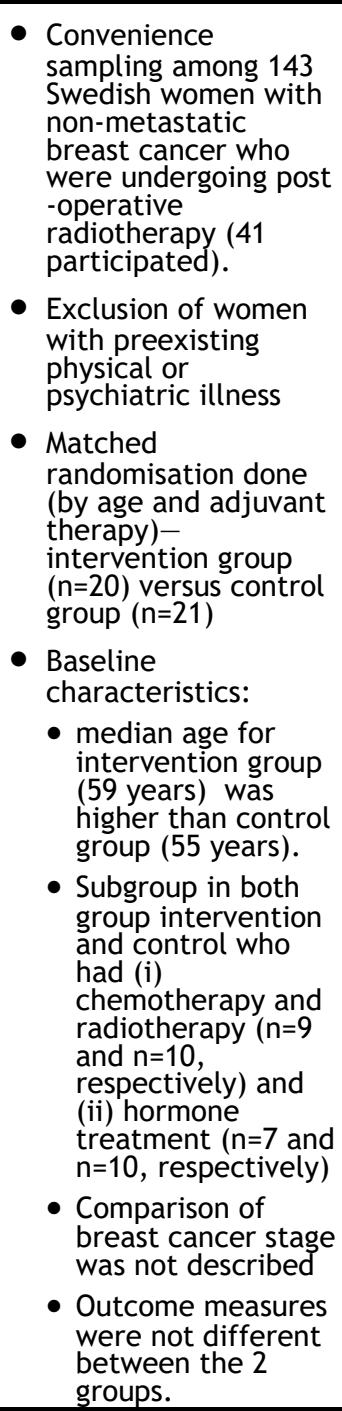 & $\begin{array}{l}\text { Tndividual sessions } \\
\text { of individual art } \\
\text { therapy therapy } \\
\text { using } \\
\text { phenomenologica } \\
\text { method (as } \\
\text { described by } \\
\text { Betensky): } \\
\text { First session: } \\
\text { visualisation of } \\
\text { feelings as } \\
\text { analogue } \\
\text { drawings } \\
\text { towards a } \\
\text { word. } \\
\text { Second session: } \\
\text { made a body } \\
\text { image and } \\
\text { encourage to } \\
\text { paint in colour } \\
\text { and forms } \\
\text { within. } \\
\text { Third and fourth } \\
\text { session: paint } \\
\text { whatever. } \\
\text { Fifth session: } \\
\text { reflection }\end{array}$ & $\begin{array}{l}\text { No } \\
\text { psychologi } \\
\text { cal } \\
\text { interventi } \\
\text { on in } \\
\text { control } \\
\text { group. }\end{array}$ & $\begin{array}{l}\text { Once a week } \\
\text { for } 5 \text { weeks } \\
\text { during } \\
\text { patients } \\
\text { radiotherapy } \\
\text { treatment. }\end{array}$ & $\begin{array}{l}\text { Measurement of } \\
\text { the following } \\
\text { scales at pre- } \\
\text { intervention, at 2- } \\
\text { month and 4- } \\
\text { monthpost } \\
\text { intervention: } \\
\text { 1. Structural } \\
\text { Analysis of Social } \\
\text { Behaviour to } \\
\text { measure } \\
\text { perceived self- } \\
\text { image - clusters } \\
\text { are divided into } \\
\text { attachment } \\
\text { clustersgroup and } \\
\text { disruptive clusters } \\
\text { group. } \\
\text { (Reliability and } \\
\text { validity in the } \\
\text { study were not } \\
\text { described) } \\
\text { Symptom Check } \\
\text { List-90 to } \\
\text { measure } \\
\text { perceived } \\
\text { symptoms-- In this } \\
\text { study only } \\
\text { General Severity } \\
\text { Index and the } \\
\text { subscales of } \\
\text { Depression, } \\
\text { Anxiety, and } \\
\text { Somatization } \\
\text { were used. } \\
\text { (Reliability and } \\
\text { validity in the } \\
\text { study were not } \\
\text { described) } \\
\text { indion }\end{array}$ \\
\hline
\end{tabular}




\begin{tabular}{|c|c|c|c|c|c|c|}
\hline $\begin{array}{l}\text { Monti } \\
\text { et al. } \\
(2013)\end{array}$ & $\begin{array}{l}\text { Parallel/ } \\
\text { superiority/ } \\
\text { confirmatory }\end{array}$ & $\begin{array}{l}\text { - Sampling method not } \\
\text { described. } \\
\text { - Among } 191 \text { American } \\
\text { women with primary } \\
\text { or recurrent breast } \\
\text { cancer, who received } \\
\text { diagnosis between } 6 \\
\text { months to } 3 \text { years } \\
\text { prior to enrolment in } \\
\text { the study. } \\
\text { - Not stated whether } \\
\text { there was exclusion } \\
\text { of women with } \\
\text { dementia or severe } \\
\text { psychiatric illness. } \\
\text { - Randomisation done- } \\
\text { intervention group } \\
\text { (n=93) versus control } \\
\text { group (n=98) } \\
\text { - Baseline } \\
\text { characteristics: } \\
\text { - Both groups were } \\
\text { comparable in } \\
\text { terms of age } \\
\text { (both: } 56+\text { years) } \\
\text { and breast cancer } \\
\text { stage. } \\
\text { - Comparison of } \\
\text { medical treatment } \\
\text { state was not } \\
\text { described. } \\
\text { - Outcome measures } \\
\text { were not different } \\
\text { between the } 2 \\
\text { groups. } \\
\text { *There exist a third } \\
\text { wing of added } \\
\text { comparison group that } \\
\text { did not receive any } \\
\text { treatment programme- } \\
\text { this group will not be } \\
\text { discussed in this review } \\
\text { as it was not part of the } \\
\text { randomisation } \\
\text { procedure. }\end{array}$ & $\begin{array}{l}\text { Mindfulness-based } \\
\text { Art Therapy: } \\
\text { - Specific art } \\
\text { therapy tasks } \\
\text { complementing } \\
\text { the Mindfulness } \\
\text { Based curriculum } \\
\text { by providing an } \\
\text { additional } \\
\text { nonverbal mode } \\
\text { of identifying and } \\
\text { organizing } \\
\text { internal and } \\
\text { external } \\
\text { representations of } \\
\text { stressors and } \\
\text { related emotions. } \\
\text { The Mindfulness } \\
\text { Based Curriculum } \\
\text { involved a variety } \\
\text { of mindfulness } \\
\text { meditation } \\
\text { techniques that } \\
\text { were taught } \\
\text { during the } \\
\text { programme } \\
\text { including body } \\
\text { scan, awareness } \\
\text { of breathing, } \\
\text { awareness of } \\
\text { emotions, and } \\
\text { mindful yoga, } \\
\text { walking, eating } \\
\text { and listening. }\end{array}$ & $\begin{array}{l}\text { Breast } \\
\text { cancer } \\
\text { support } \\
\text { group } \\
\text { educational } \\
\text { programme } \\
\text { - To provide } \\
\text { breast } \\
\text { cancer } \\
\text { patients } \\
\text { with } \\
\text { support and } \\
\text { resources to } \\
\text { maximize } \\
\text { quality of } \\
\text { life. Most } \\
\text { sessions } \\
\text { included an } \\
\text { expert } \\
\text { speaker on } \\
\text { a topic } \\
\text { (such as } \\
\text { navigating } \\
\text { long-term } \\
\text { care, diet } \\
\text { and fitness } \\
\text { or coping } \\
\text { with cancer } \\
\text { recurrence) } \\
\text {, and there } \\
\text { was time in } \\
\text { each group } \\
\text { for sharing } \\
\text { and } \\
\text { supportive } \\
\text { exchanges. }\end{array}$ & $\begin{array}{l}8 \text { weeks } \\
\text { programme }\end{array}$ & $\begin{array}{l}\text { Measurement } \\
\text { of the following } \\
\text { scales at week- } \\
\text { 1, week-9 } \\
\text { (week-1 post- } \\
\text { intervention) } \\
\text { and week-36 } \\
\text { (week-28 post } \\
\text { intervention): } \\
\text { 1. Symptom } \\
\text { Check List-90 } \\
\text { to measure } \\
\text { perceived } \\
\text { symptoms-- In } \\
\text { this study } \\
\text { General } \\
\text { Severity Index } \\
\text { and the } \\
\text { subscales of } \\
\text { Somatization, } \\
\text { Obsession, } \\
\text { Interpersonal } \\
\text { sensitivity, } \\
\text { Depression, } \\
\text { Anxiety, } \\
\text { Hostility, } \\
\text { Phobic, } \\
\text { Paranoid, and } \\
\text { Psychotic } \\
\text { symptomswere } \\
\text { used. } \\
\text { (Reliability and } \\
\text { validity in the } \\
\text { study were not } \\
\text { described) } \\
\text { 2. Medical } \\
\text { Outcomes } \\
\text { Study Short- } \\
\text { Form Health } \\
\text { Survey (SF-36) } \\
\text { to measure } \\
\text { health-related } \\
\text { quality of life. }\end{array}$ \\
\hline $\begin{array}{l}\text { Oster } \\
\text { et al. } \\
\text { (2014) }\end{array}$ & $\begin{array}{l}\text { Parallel/ } \\
\text { superiority/ } \\
\text { exploratory }\end{array}$ & $\begin{array}{l}\text { - Purposive sampling } \\
\text { among } 37 \text { Swedish } \\
\text { women who were } \\
\text { breast cancer } \\
\text { survivors(post- } \\
\text { operative } \\
\text { radiotherapy) and } \\
\text { had participated in a } \\
\text { previous study (Oster } \\
\text { et al. 2006). } \\
\text { - Exclusion of only } \\
\text { women with } \\
\text { dementia or severe } \\
\text { psychiatric illness. } \\
\text { - Randomisation done- } \\
\text { intervention group } \\
\text { (n=18) versus control } \\
\text { group (n=19) } \\
\text { - Baseline } \\
\text { characteristics: } \\
\text { - Median age for } \\
\text { intervention group } \\
\text { (66.5 years) was } \\
\text { higher than control } \\
\text { group (61 years). } \\
\text { - Comparison of } \\
\text { breast cancer stage } \\
\text { and medical } \\
\text { treatment state not } \\
\text { described. } \\
\text { - Outcome measures } \\
\text { were not different } \\
\text { between the } 2 \\
\text { groups. }\end{array}$ & $\begin{array}{l}\text { Tndividual art } \\
\text { therapy session } \\
\text { once a week during } \\
\text { radiotherapy } \\
\text { (specific method } \\
\text { was not described } \\
\text { in this article-have } \\
\text { to be refered to } \\
\text { Oster et al (2006)) }\end{array}$ & $\begin{array}{l}\text { Procedure in } \\
\text { control } \\
\text { group was } \\
\text { not } \\
\text { described. }\end{array}$ & $\begin{array}{l}\text { Once a } \\
\text { week for } 5 \\
\text { weeks } \\
\text { during } \\
\text { patients' } \\
\text { radiothe- } \\
\text { rapy } \\
\text { treatment }\end{array}$ & $\begin{array}{l}\text { - Measurement } \\
\text { of the } \\
\text { following } \\
\text { scales at } 2 \\
\text { months, } 6 \\
\text { months and 5-7 } \\
\text { years post } \\
\text { intervention: } \\
\text { 1. WHOQOL-BREF } \\
\text { to identify } \\
\text { Quality of Life } \\
\text { and general } \\
\text { health - } 4 \\
\text { domains } \\
\text { physical } \\
\text { health, } \\
\text { psychological } \\
\text { health, social } \\
\text { relationship } \\
\text { and } \\
\text { environment. } \\
\text { (Reliability and } \\
\text { validity in the } \\
\text { study were not } \\
\text { described) } \\
\text { Note: The Coping } \\
\text { Resource } \\
\text { Inventory result } \\
\text { that was reported } \\
\text { in this article was } \\
\text { a repetition of } \\
\text { the result in the } \\
\text { article by Oster } \\
\text { et al. (2006). }\end{array}$ \\
\hline
\end{tabular}




\begin{tabular}{|c|c|c|c|c|}
\hline Study & $\begin{array}{l}\text { Positive Psychology } \\
\text { Domain Outcome(s) }\end{array}$ & Mental Illness Domain Outcome & Quality of Life Domain outcome & Conclusion \\
\hline $\begin{array}{l}\text { Oster } \\
\text { et } \mathrm{al} \text {. } \\
(2006)\end{array}$ & $\begin{array}{l}\text { Coping Resource } \\
\text { Inventory Mean } \\
\text { Total Score: } \\
\text { - After } 2 \text { months } \\
\text { post- } \\
\text { intervention: } \\
\text { - Intervention } \\
\text { Group: } 257.2 \\
( \pm 28.7) \\
\text { - Control Group: } \\
233.6( \pm 44.1) \\
\text { - p=0.050 [Cohen’s } \\
\text { d: } 0.63] \\
\text { - After } 6 \text { months } \\
\text { post- } \\
\text { intervention: } \\
\text { - Intervention } \\
\text { Group: } 256.3 \\
( \pm 25.9) \\
\text { - Control Group: } \\
240.0( \pm 34.9) \\
\text { - p=0.098 [Cohen’s } \\
\text { d: } 0.53] \\
\end{array}$ & & & $\begin{array}{l}\text { As a whole, there } \\
\text { was no difference of } \\
\text { efficacy between } \\
\text { the art therapy } \\
\text { group and control } \\
\text { group in terms of } \\
\text { coping resource, }\end{array}$ \\
\hline $\begin{array}{l}\text { Puig } \\
\text { et al. } \\
\text { (2006) }\end{array}$ & $\begin{array}{l}\text { Emotional } \\
\text { Approach Coping } \\
\text { Scale after } 4 \\
\text { weeks: } \\
\text { - Intervention } \\
\text { Group: Not } \\
\text { reported } \\
\text { - Control Group: } \\
\text { Not reported } \\
\text { - p>0.05 }\end{array}$ & $\begin{array}{l}\text { Profile of Mood States (Relevant } \\
\text { constructs) after } 4 \text { weeks: } \\
\text { - Depression-dejection mean: } \\
\text { - Intervention Group: } 20.66 \\
( \pm 4.74) \\
\text { - Control Group: } 26.34( \pm 8.48) \\
\text { - p<0.05* [Cohen’s d: } 0.83 \text { ] } \\
\text { - Tension-anxiety mean: } \\
\text { - Intervention Group: } 17.31 \\
( \pm 5.01) \\
\text { - Control Group: } 20.32( \pm 5.24) \\
\text { - p<0.05* [Cohen’s d: } 0.59]\end{array}$ & & $\begin{array}{l}\text { There is evidence of } \\
\text { efficacy of art } \\
\text { therapy in terms of } \\
\text { mood improvement } \\
\text { (depression and } \\
\text { anxiety constructs) } \\
\text { after } 4 \text { weeks post- } \\
\text { intervention. } \\
\text { However, there was } \\
\text { no improvement } \\
\text { difference in terms } \\
\text { of emotional coping } \\
\text { resource. }\end{array}$ \\
\hline $\begin{array}{l}\text { Svensk } \\
\text { et al. } \\
(2009)\end{array}$ & & & $\begin{array}{l}\text { WHOQOL-BREF Mean Overall } \\
\text { Score: } \\
\text { - After } 2 \text { months post- } \\
\text { intervention: } \\
\text { - Intervention Group: } 75.0 \\
\text { - }( \pm 21.5) \\
\text { - Control Group: } 72.6( \pm 15.6) \\
\text { - p>0.05 [Cohen’s d: } 0.13 \text { ] } \\
\text { - After } 6 \text { months post- } \\
\text { intervention: } \\
\text { - Intervention Group: } 85.0 \\
\text { - }( \pm 12.6) \\
\text { - Control Group: } 67.5( \pm 20.0) \\
\text { - p=0.003* [Cohen’s d: } 1.05 \text { ] }\end{array}$ & $\begin{array}{l}\text { There is evidence of } \\
\text { efficacy of art } \\
\text { therapy in terms of } \\
\text { quality of life } \\
\text { improvement after } 6 \\
\text { months post- } \\
\text { intervention. }\end{array}$ \\
\hline $\begin{array}{l}\text { Thyme } \\
\text { et al. } \\
(2009)\end{array}$ & & $\begin{array}{l}\text { Symptom Check List-90 Mean } \\
\text { General Severity lndex: } \\
\text { - After } 2 \text { months post- } \\
\text { intervention: } \\
\text { - Intervention Group: } 0.32 \\
( \pm 0.31) \\
\text { - Control Group: } 0.40( \pm 0.31) \\
\text { - p>0.05 [Cohen’s d: } 0.26 \text { ] } \\
\text { - After } 4 \text { months post- } \\
\text { intervention: } \\
\text { - Intervention Group: } 0.19 \\
( \pm 0.16) \\
\text { - Control Group: } 0.34( \pm 0.28) \\
\text { - p<0.05* [Cohen’s d: } 0.03 \text { ] }\end{array}$ & & $\begin{array}{l}\text { There is evidence of } \\
\text { efficacy of art } \\
\text { therapy in terms of } \\
\text { general distress (i.e. } \\
\text { general severity of } \\
\text { psychiatric } \\
\text { symptoms) } \\
\text { improvement after } 4 \\
\text { months post- } \\
\text { intervention. }\end{array}$ \\
\hline $\begin{array}{l}\text { Monti } \\
\text { et al. } \\
\text { (2013) }\end{array}$ & & $\begin{array}{l}\text { Symptom Check List-90 Adjusted } \\
\text { Mean General Severity Index: } \\
\text { - After } 1 \text { week post- } \\
\text { intervention: } \\
\text { - Intervention Group: } 0.72 \\
\text { - Control Group: } 0.65 \\
\text { - p>0.05 } \\
\text { - After } 28 \text { weeks post- } \\
\text { intervention: } \\
\text { - Intervention Group: } 0.69 \\
\text { - Control Group: } 0.68 \\
\text { - p>0.05 }\end{array}$ & $\begin{array}{l}\text { SF-36 Adjusted Mean (General } \\
\text { Health): } \\
\text { - After } 1 \text { week post- } \\
\text { intervention: } \\
\text { - Intervention Group: } 62.56 \\
\text { - Control Group: } 65.21 \\
\text { - The main effect significance } \\
\text { level was not reported. } \\
\text { - After } 28 \text { weeks post- } \\
\text { intervention: } \\
\text { - Intervention Group: } 62.98 \\
\text { - Control Group: } 65.05 \\
\text { - The main effect significance } \\
\text { level was not reported. }\end{array}$ & $\begin{array}{l}\text { Ambiguous } \\
\text { conclusion in terms } \\
\text { of general distress } \\
\text { and quality of life } \\
\text { improvement for art } \\
\text { therapy if compared } \\
\text { to control. }\end{array}$ \\
\hline
\end{tabular}


Con't

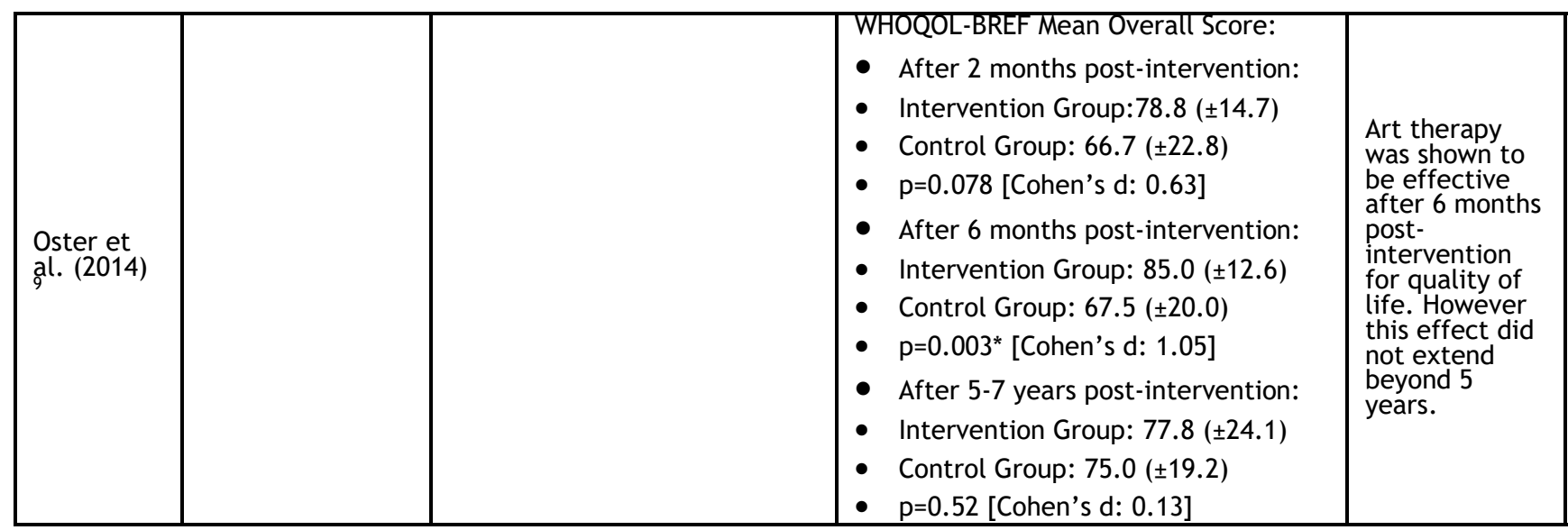

*: Significance at level of $\mathrm{p}<0.05$ (two-tailed)

Table III: Quality of methods and results reported in studies included in the review (based on CONSORT Statements).

\begin{tabular}{|c|c|c|c|c|c|c|c|c|}
\hline \multirow[b]{2}{*}{ Section } & \multirow{2}{*}{$\begin{array}{l}\text { Item } \\
\text { in } \\
\text { CONS } \\
\text { ORT }\end{array}$} & \multirow[b]{2}{*}{ CONSORT Checklist } & \multicolumn{6}{|c|}{ Status in article } \\
\hline & & & $\begin{array}{l}\text { Oster et } \\
\text { al. (2006) } \\
14\end{array}$ & $\begin{array}{l}\text { Puig et } \\
\text { al. (2006) } \\
15\end{array}$ & $\begin{array}{l}\text { Svensk et } \\
\text { al. (2009) } \\
\text { 16 }\end{array}$ & $\begin{array}{l}\text { Thyme } \\
\text { et al. } \\
(2009)^{17}\end{array}$ & $\begin{array}{l}\text { Monti et } \\
\text { al. } \\
(2013)^{18}\end{array}$ & $\begin{array}{l}\text { Oster et } \\
\text { al. } \\
\text { (2014) }\end{array}$ \\
\hline \multicolumn{9}{|l|}{ METHODS } \\
\hline \multirow[t]{2}{*}{ Trial design } & $3 a$ & $\begin{array}{l}\text { Description of trial } \\
\text { design (such as } \\
\text { parallel, factorial) } \\
\text { including allocation } \\
\text { ratio }\end{array}$ & $\mathrm{C}$ & A & A & A & A & A \\
\hline & $3 b$ & $\begin{array}{l}\text { Important changes to } \\
\text { methods after trial } \\
\text { commencement (such } \\
\text { as eligibility criteria), } \\
\text { with reasons }\end{array}$ & A & A & A & $E$ & $E$ & $E$ \\
\hline \multirow[t]{2}{*}{ Participants } & $4 a$ & $\begin{array}{l}\text { Eligibility criteria for } \\
\text { participants }\end{array}$ & A & $\mathrm{A}$ & A & $A$ & A & A \\
\hline & $4 b$ & $\begin{array}{l}\text { Settings and locations } \\
\text { where the data were } \\
\text { collected }\end{array}$ & B & $\mathrm{E}$ & $\mathrm{A}$ & A & B & B \\
\hline Interventions & 5 & $\begin{array}{l}\text { The interventions for } \\
\text { each group with } \\
\text { sufficient details to } \\
\text { allow replication, } \\
\text { including how and } \\
\text { when they were } \\
\text { actually administered }\end{array}$ & B & B & A & A & A & B \\
\hline \multirow[t]{2}{*}{ Outcomes } & $6 a$ & $\begin{array}{l}\text { Completely defined } \\
\text { pre-specified primary } \\
\text { and secondary } \\
\text { outcome measures, } \\
\text { including how and } \\
\text { when they were } \\
\text { assessed }\end{array}$ & B & B & A & A & A & A \\
\hline & $6 \mathrm{~b}$ & $\begin{array}{l}\text { Any changes to trial } \\
\text { outcomes after the } \\
\text { trial commenced, } \\
\text { with reasons }\end{array}$ & B & $\mathrm{C}$ & A & B & $E$ & C \\
\hline \multirow[t]{2}{*}{ Sample size } & $7 a$ & $\begin{array}{l}\text { How sample size was } \\
\text { determined }\end{array}$ & $\mathrm{D}$ & $D$ & $\mathrm{D}$ & $\mathrm{D}$ & $\mathrm{D}$ & $\mathrm{D}$ \\
\hline & $7 \mathrm{~b}$ & $\begin{array}{l}\text { When applicable, } \\
\text { explanation of any } \\
\text { interim analyses and } \\
\text { stopping guidelines }\end{array}$ & NA & $\mathrm{E}$ & B & C & NA & NA \\
\hline \multicolumn{9}{|l|}{ Randomisation: } \\
\hline \multirow[t]{2}{*}{$\begin{array}{l}\text { Sequence } \\
\text { generation }\end{array}$} & $8 a$ & $\begin{array}{l}\text { Method used to } \\
\text { generate the random } \\
\text { allocation sequence }\end{array}$ & B & C & A & $E$ & B & $\mathrm{C}$ \\
\hline & $8 b$ & $\begin{array}{l}\text { Type of } \\
\text { randomisation; } \\
\text { details of any } \\
\text { restriction (such as } \\
\text { blocking and block } \\
\text { size) }\end{array}$ & $\mathrm{A}$ & $\mathrm{C}$ & $A$ & $E$ & A & C \\
\hline
\end{tabular}




\begin{tabular}{|c|c|c|c|c|c|c|c|c|}
\hline $\begin{array}{l}\text { Allocation } \\
\text { concealment } \\
\text { mechanism }\end{array}$ & 9 & $\begin{array}{l}\text { Mechanism used to } \\
\text { implement the random } \\
\text { allocation sequence (such as } \\
\text { sequentially numbered } \\
\text { containers), describing any } \\
\text { steps taken to conceal the } \\
\text { sequence until interventions } \\
\text { were assigned }\end{array}$ & $B$ & $C$ & $\bar{A}$ & $E$ & $B$ & $C$ \\
\hline $\begin{array}{l}\text { Tmplementati } \\
\text { on }\end{array}$ & 10 & $\begin{array}{l}\text { Who generated the random } \\
\text { allocation sequence, who } \\
\text { enrolled participants, and } \\
\text { who assigned participants to } \\
\text { interventions }\end{array}$ & $D$ & $C$ & $C$ & $C$ & B & $C$ \\
\hline \multirow[t]{2}{*}{ Blinding } & $11 a$ & $\begin{array}{l}\text { If done, who was blinded } \\
\text { after assignment to } \\
\text { interventions (for example, } \\
\text { participants, care providers, } \\
\text { those assessing outcomes) } \\
\text { and how }\end{array}$ & $\mathrm{D}$ & $C$ & $C$ & $C$ & $\mathrm{~B}$ & $C$ \\
\hline & $11 \mathrm{~b}$ & $\begin{array}{l}\text { If relevant, description of } \\
\text { the similarity of } \\
\text { interventions }\end{array}$ & C & $C$ & $C$ & $B$ & $A$ & $E$ \\
\hline \multirow[t]{2}{*}{$\begin{array}{l}\text { Statistical } \\
\text { methods }\end{array}$} & $12 a$ & $\begin{array}{l}\text { Statistical methods used to } \\
\text { compare groups for primary } \\
\text { and secondary outcomes }\end{array}$ & $\bar{A}$ & $\bar{A}$ & $\bar{A}$ & $\bar{A}$ & $\bar{A}$ & $\bar{A}$ \\
\hline & $12 b$ & $\begin{array}{l}\text { Methods for additional } \\
\text { analyses, such as subgroup } \\
\text { analyses and adjusted } \\
\text { analyses }\end{array}$ & $\bar{A}$ & $\bar{A}$ & $A$ & $\bar{A}$ & $A$ & $A$ \\
\hline \multicolumn{9}{|l|}{ RESULTS } \\
\hline \multirow[t]{2}{*}{$\begin{array}{l}\text { Participant } \\
\text { flow (a } \\
\text { diagram is } \\
\text { strongly } \\
\text { recommende } \\
\text { d) }\end{array}$} & $13 a$ & $\begin{array}{l}\text { For each group, the numbers } \\
\text { of participants who were } \\
\text { randomly assigned, received } \\
\text { intended treatment, and } \\
\text { were analysed for the } \\
\text { primary outcome }\end{array}$ & B & B & $\bar{A}$ & $\bar{A}$ & $\bar{A}$ & $E$ \\
\hline & $13 \mathrm{~b}$ & $\begin{array}{l}\text { For each group, losses and } \\
\text { exclusions after } \\
\text { randomisation, together } \\
\text { with reasons }\end{array}$ & B & $B$ & $\bar{A}$ & $\bar{A}$ & $\bar{A}$ & $A$ \\
\hline \multirow[t]{2}{*}{ Recruitment } & $14 a$ & $\begin{array}{l}\text { Dates defining the periods of } \\
\text { recruitment and follow-up }\end{array}$ & $B$ & $B$ & $\bar{A}$ & $\bar{A}$ & $A$ & $\bar{A}$ \\
\hline & $14 b$ & $\begin{array}{l}\text { Why the trial ended or was } \\
\text { stopped }\end{array}$ & $\mathrm{D}$ & $\bar{A}$ & $\bar{A}$ & $\bar{A}$ & $\bar{A}$ & $A$ \\
\hline Baseline data & 15 & $\begin{array}{l}\text { A table showing baseline } \\
\text { demographic and clinical } \\
\text { characteristics for each } \\
\text { group }\end{array}$ & D & B & $\bar{A}$ & $\bar{A}$ & $\bar{A}$ & $\bar{A}$ \\
\hline $\begin{array}{l}\text { Numbers } \\
\text { analysed }\end{array}$ & 16 & $\begin{array}{l}\text { For each group, number of } \\
\text { participants (denominator) } \\
\text { included in each analysis } \\
\text { and whether the analysis } \\
\text { was by original assigned } \\
\text { groups }\end{array}$ & $\mathrm{B}$ & $\bar{A}$ & $\bar{A}$ & $\bar{A}$ & $A$ & $\bar{A}$ \\
\hline \multirow[t]{2}{*}{$\begin{array}{l}\text { Outcomes } \\
\text { and } \\
\text { estimation }\end{array}$} & $17 a$ & $\begin{array}{l}\text { For each primary and } \\
\text { secondary outcome, results } \\
\text { for each group, and the } \\
\text { estimated effect size and its } \\
\text { precision (such as } 95 \% \\
\text { confidence interval) }\end{array}$ & $\bar{A}$ & $B$ & $A$ & $B$ & $\bar{A}$ & $\bar{A}$ \\
\hline & $17 \mathrm{~b}$ & $\begin{array}{l}\text { For binary outcomes, } \\
\text { presentation of both } \\
\text { absolute and relative effect } \\
\text { sizes is recommended }\end{array}$ & NA & NA & NA & NA & $A$ & NA \\
\hline $\begin{array}{l}\text { Ancillary } \\
\text { analyses }\end{array}$ & 18 & $\begin{array}{l}\text { Results of any other analyses } \\
\text { performed, including } \\
\text { subgroup analyses and } \\
\text { adjusted analyses, } \\
\text { distinguishing pre-specified } \\
\text { from exploratory }\end{array}$ & NA & NA & NA & $\mathrm{NA}$ & $\bar{A}$ & $\bar{A}$ \\
\hline Harms & 19 & $\begin{array}{l}\text { All important harms or } \\
\text { unintended effects in each } \\
\text { group }\end{array}$ & $B$ & $C$ & $C$ & $C$ & $C$ & $C$ \\
\hline
\end{tabular}

Evaluation of quality:

A: Acceptable ; B: Some minor weaknesses; C: Some major weaknesses; D: Not acceptable; E: Ambiguous; NA: Not applicable 


\section{DISCUSSION AND CONCLUSION}

Through a careful review of the current literature, we found that there is a serious lack of good quality RCT studies in answering whether art therapy (via creative paintings) is worth the while to be done among breast cancer patients. One of the issues that predominated in this systematic review is the heterogeneity of the multiple types of outcomes for mental health. This prevents a cohesive conclusion to be drawn. For example, an improvement of mood does not automatically means that the quality of life will also improve. The use of weighted outcome (i.e., selecting the main outcome) for mental health measurements may be problematic. This is due to the inherent subjective nature of psychological-based outcomes that may have different significant phenomenological significance for each separate individuals. The phenomenological view towards mental health was elegantly summarised in a review by Aho $(2008)^{24}$ as a world that "is not understood mechanistically as an aggregate of real physical objects in causal interaction, but, rather is the meaning of being".

The current systematic review suffers from several limitations that cannot be avoided due to the lack of resources. Firstly, we cannot effectively control for the effect of publication bias. ${ }^{25}$ However, there is a lack of statistical evidence to conclude the publication bias (e.g. absence funnel shape pattern of Forest Plot) as we did not manage to convert the systematic review into a meta-analysis. ${ }^{26}$ Hence, future systematic reviews on this topic should strive for a single primary mental health outcome measure during data extraction that would help the synthesis of studies to be done as a proper metaanalysis. All of this will be possible if there are more original RCTs on this topic in the coming years. Besides that, future researchers should use and decide on a "gold standard" quantitative measurement of the most important mental health outcome for such studies. They should also try to use a "gold standard" comparative treatment group, such as Cognitive behavioural therapy (CBT). Via these two last suggestions, a future systematic review will be more conclusive than the current one.

There is inconclusive evidence of the efficacy of art therapy (via creative paintings) for the improvement of mental health outcomes among female breast cancer patients. The main reason for this inconclusiveness is primarily due to the lack of studies with acceptable quality, rather than the lack of evidence itself as there were four studies with promising results. Hence, we found no strong reason to recommend the adoption of art therapy as a therapy of choice for the treatment of psychosocial distress among breast cancer patients in the public health setting for now.

\section{REFERENCES}

1. World Health Organization. The global burden of disease: 2004 update.

Geneva: World Health Organization, 2008.

2. Burgess C, Cornelius V, Love S, et al. Depression and anxiety in women with early breast cancer: five year observational cohort study. BMJ 2005; 330:702.

3. Fann JR, Thomas-Rich AM, Katon WJ, et al. Major depression after breast cancer: a review of epidemiology and treatment. Gen Hosp Psychiatry 2008; 30:112-6.

4. Williams S, Dale J. The effectiveness of treatment for depression/depressive symptoms in adults with cancer: a systematic review. $\mathrm{Br} \mathrm{J}$ Cancer 2006; 94:372-90.

5. Case C, Dalley T. The handbook of art therapy. 2nd ed. East Sussex: Routledge, 2010.

6. Malchiodi C. Handbook of art therapy. New York, NY: Guilford Press, 2003.

7. Aldous CR. Creativity in problem solving: Uncovering the origin of new ideas. International Education Journal 2005; 5:43-56.

8. Malchiodi C. The Art Therapy Sourcebook. New York: McGraw Hill-NTC, 1998.

9. Vick RM. A brief history of art therapy. In: Malchiodi CA, eds. Handbook of art therapy New York: Guilford Press, 2003: 5-15.

10. Slayton S, D'Archer J, Kaplan F. Outcome Studies on the Efficacy of Art Therapy: A Review of Findings. Art Therapy 2010; 27:108-18.

11. Archer S, Buxton S, Sheffield D. The effect of creative psychological interventions on psychological outcomes for adult cancer patients: a systematic review of randomised controlled trials. Psycho-Oncology 2015; 24:110.

12. Boehm K, Cramer H, Staroszynski T, Ostermann T. Arts therapies for anxiety, depression, and quality of life in breast cancer patients: a 
systematic review and meta-analysis. Evid Based Complement Alternat Med 2014; 2014:103297.

13. Needleman IG. A guide to systematic reviews. J Clin Periodontol 2002; 29 Suppl 3:6-9; discussion 37-8.

14. Oster I, Svensk AC, Magnusson E, et al. Art therapy improves coping resources: a randomized, controlled study among women with breast cancer. Palliat Support Care 2006; 4:57-64.

15. Puig A, Lee SM, Goodwin L, Sherrard PAD. The efficacy of creative arts therapies to enhance emotional expression, spirituality, and psychological well-being of newly diagnosed Stage I and Stage II breast cancer patients: A preliminary study. The Arts in Psychotherapy 2006; 33:218-28.

16. Svensk AC, Oster I, Thyme KE, et al. Art therapy improves experienced quality of life among women undergoing treatment for breast cancer: a randomized controlled study. Eur J Cancer Care (Engl) 2009; 18:69-77.

17. Thyme KE, Sundin EC, Wiberg B, et al. Individual brief art therapy can be helpful for women with breast cancer: A randomized controlled clinical study. Palliat Support Care 2009; 7:87-95.

18. Monti DA, Kash KM, Kunkel EJ, et al. Psychosocial benefits of a novel mindfulness intervention versus standard support in distressed women with breast cancer. Psychooncology 2013; 22:2565-75.

19. Oster I, Tavelin B, Thyme KE, et al. Art therapy during radiotherapy - A five-year follow-up study with women diagnosed with breast cancer. The Arts in Psychotherapy 2014; 41:3640.

20. Egger M, Dickersin K, Smith GD. Problems and limitations in conducting systematic reviews. In: Egger M, Smith GD, Altman DG, eds. Systematic reviews in health care: Meta-analysis in context. London: BMJ Publishing Group, 2001.

21. Cohen J. Statistical Power Analysis for the Behavioral Sciences. 2nd ed. New Jersey: Lawrence Erlbaum Associates, 1988.

22. Moher D, Hopewell S, Schulz KF, et al. CONSORT 2010 Explanation and Elaboration: Updated guidelines for reporting parallel group randomised trials. J Clin Epidemiol 2010; 63 (8):e1-37.

23. Betensky MG. What Do You See? Phenomenology of Therapeutic Art Expression. London and philadelphia, PA: Jessica Kingsley Publishers, 1995.

24. Aho K. Medicalizing mental health: a phenomenological alternative. J Med Humanit 2008; 29:243-59.

25. Sica GT. Bias in research studies. Radiology 2006; 238:780-9.

26. Sterne JA, Egger M. Funnel plots for detecting bias in meta-analysis: guidelines on choice of axis. J Clin Epidemiol 2001; 54:1046-55. 